\title{
STAVE VESSELS AS PART OF POST MORTEM FURNISHINGS IN EARLY MEDIEVAL POLAND - A PROBLEM OUTLINE AND RESEARCH PERSPECTIVES
}

\begin{abstract}
In Polish archaeological literature there is no systematic and broad-scale formal-typological and chronological analysis of stave vessels (buckets), which were part of grave goods in Early Medieval cemeteries in the present-day territory of Poland. Furthermore, hardly anything has been said with regard to their sepulchral function. The knowledge concerning this category of finds is still not systematised and is scattered in monograph works on individual sites, in broader compendia dealing with funeral rites and in various minor works. It is therefore recommended to offer a brief overview of research on this category of finds. Author discusses the issues of terminology, the current state of research and the most ardent research needs related to the issue mentioned in the title of this paper.
\end{abstract}

Keywords: buckets, Early Middle Ages, cemeteries, grave goods, state of research, Poland

In Polish archaeological literature there is no systematic and broad-scale formal-typological and chronological analysis of stave vessels, which were part of grave goods in Early Medieval cemeteries in the present-day territory of Poland. Furthermore, hardly anything has been said with regard to their sepulchral function. The knowledge concerning this category of finds is still not systematised and is scattered in monograph works on individual sites, in broader compendia dealing with funeral rites and in various minor works ${ }^{1}$. It is therefore recommended to offer a brief overview of research on this category of finds, also taking into consideration research needs in this field.

It seems good to start with issues of terminology. Various kinds of stave vessels are isolated in archaeological materials, and containers discovered in graves are usually referred to as buckets, or (very sporadically) as vats $(\text { Polish ceber) })^{2}$ or scoops (Polish czerpak) $)^{3}$. Gathered data suggests that these were open containers, constructed from wooden staves and bottoms and provided with metal parts: hoops (bindings), catches (handles), bows (bails), chapes, rivets and nails, sometimes also metal sheet fittings (bands, appliqués). Staves formed the vessel's body (so-called "side"). However, not every vessel was provided with the afore-mentioned metal parts and this is not only a result of

Our knowledge of vessels from earlier periods seems to be much better. These vessels were discussed by J. Szydłowski (1984), mainly on the basis of sepulchral finds.

Rajewski 1937, 74.

3 Florek 2006, 410. their complete decomposition when buried in the soil for a long time. Therefore, one should reject the existence of a steady canon defining the shape of a vessel, which would result from using a permanently recurrent set of the mentioned parts. One's attention is first of all drawn to the often observed lack of bows. This, combined with the usually small capacity of these vessels, suggests a reconsideration of terminology which is used in scholarship.

According to the most general present-day definition, a bucket is a vessel usually made from a metal sheet, with a cylindrical shape, slightly widening at the top, with a bow. Its capacity is about 10-12 litres and it is used to carry water, coal, refuse; a bin ${ }^{4}$, a vessel which widens at the top, with a bail, used for water, coal, refuse etc.; bin $^{5}$. Leaving aside the question of the shape and function (as it is of secondary importance here), a distinctive feature is the presence of the bow. Archaeological and ethnographic works concerning woodworking also define buckets as vessels provided with bows (bails), no matter whether they are made from wood or metal ${ }^{6}$. On the other hand, as said above, some "grave" vessels did not have bails ${ }^{7}$, and were of small capacity. In such cases, it would be more proper to use the term "mug," which is used for tableware with a capacity of 1-2 litres (sometimes

\footnotetext{
Stownikjęzyka polskiego... 1997, 972. Maty stownik... 1990, 888.

6 Cf. for example Barnycz-Gupieniec 1959, 35ff;
} Kaźmierczyk 1965, 484ff; Moszyński 1967, 307, Fig. 259; Dołżycka 1996, 183. Buckets are vessels with handle, used to carry liquids, mainly water (Niesiołowska-Wędzka 1980, 407).

7 However, the use of bows made from organic materials cannot be completely excluded. 
even 3 litres), with no bows ${ }^{8}$. However, it is possible to point to finds which were provided with bails, in spite of their small size. Such finds were discovered, i.a., at Sowinki ${ }^{9}$ and Czersk $^{10}$.

It is also worth making a comment concerning the aforementioned other term, which is sometimes used in reference to stave vessels discovered in cemeteries. It is a vat (Polish ceber or cebrzyk) - in cooperage, this term is used for a bucket-like open stave vessel. Instead of a bail, it is provided with two opposite handles, formed by upper parts of staves which protrude over the upper rim of the vessel. Each of such staves has an opening. Furthermore, vats are of greater size than buckets $^{11}$. It cannot be excluded that vessels of similar forms also found their way to graves ${ }^{12}$, the more so because they can be isolated in materials coming from settlement sites in a strict sense. On the other hand, it must be stressed that the capacity of vats was greater than that of even the most capacious buckets which can be found in graves ${ }^{13}$.

Eventually, it is also worth paying attention to a possibility of using other raw materials than wood to manufacture bodies of discussed vessels. It is possible that some containers were made from raw materials which are even more prone to decomposition, such as leather or cloth. Such a possibility has recently been suggested with regard to some finds from the cemetery in Pien' ${ }^{14}$. On the other hand, until this supposition is fully verified by archaeological sources, one should assume that it was stave vessels that found their way to graves.

On the basis of the above considerations it can be said that in works dealing with sepulchral finds the term bucket (or small bucket) is used with some semantic arbitrariness. In this paper, however, it was decided not to introduce a precise terminological distinction. Thanks to this, there was no need to precisely define some of analysed vessels and some methodological difficulties could be avoided. Namely, it is possible to point to finds which were provided with bails, in spite of their small capacities. It is also possible that this part of the vessel may have completely decomposed (as made

8 Cf. Barnycz-Gupieniec 1959, 35, Fig. IX:2; Woźnicka 1961, 14, 41, Fig. IV:2; Kaźmierczyk 1965, 491-493, Fig. 17-18.

9 Krzyszowski 2014, Fig. 9:1.

10 Bronicka-Rauhut 1998, Fig. 83:5.

11 Itman 1955, 19-20, Fig. IX:1; Świderski 1966, 11, Fig. 2:a; cf. also Moszyński 1967, 307, Figs. 258, 261:5.

12 It is possible that some 'buckets' which do not have bows were vats - Rajewski 1937, 74.

13 For instance, remains of vessels with a capacity of 17-26 litres were found in layers of the Gdańsk stronghold. In one case, a 35-litre vat was discovered (Barnycz-Gupieniec 1959, 37, Figs. $\mathrm{X}: 4-6)$. Another item, whose capacity was assessed at 26 litres, is known from the stronghold in Opole (Kaźmierczyk 1965, 494, Fig. 21). Another two vessels (7-14 litres) were also discovered at this site; however, their classification as vats is dubious (Kaźmierczyk $1965,494)$.

14 Janowski and Kurasiński 2008, 79-80; Drozd et al. 2009, 354; Janowski 2013, 399. from organic materials) or it could not be identified in the mass of fittings (often small and strongly corroded) which were deposited into the grave.

\section{$* *$}

The earliest discoveries of burials containing buckets were made in the second half of the $19^{\text {th }} \mathrm{c}$. and the beginning of the $20^{\text {th }} \mathrm{c}$. What we mean here are first of all finds from explorations of cemeteries in Masovia-Blichowo, Chudzyno, Karwowo-Orszymowice, Korzybie Duże (Wielkie), Koziminy Nowe, Pieścidła, Streszewo-Kaliski, Święcice, Turowo, Wierzbica Szlachecka, Zbyszyno ${ }^{15}$ and Podlachia - Czarna Wielka, Pajewo, Rostki ${ }^{16}$, as well as in Pomerelia-Kosakowo, Leźno, Strzekęcino (Strzekocin?) ${ }^{17}$. Early discoveries of the discussed vessels in cemeteries were also made in Greater Poland - Biechowo, Wierzenica ${ }^{18}$, and in Silesia - Tyniec Mały, Warzyn ${ }^{19}$. This assemblage can be completed with incidental finds, among others, from Iwno ${ }^{20}$, Wrocław (Psie Pole-Kłokoczyce) ${ }^{21}$, Łubowo ${ }^{22}$ and Małkowice ${ }^{23}$.

Observations which were made in the earliest reports are usually of informational and descriptive nature, and they generally lack a broader comparative analysis. A considerable part of them are of minor cognitive value for the discussed issue, as they are usually limited to statements on the presence of a vessel in a grave, with no closer description of it and with no information on the context of the discovery. Furthermore, it was not always possible to propose a correct assessment of surviving remains of discussed finds. We first of all mean a hoop which was incidentally discovered in 1882 in Ciecholub and was classified as eine Krone aus Eisen $^{24}$. The nature of the find was perhaps not fully realised, either, in the case of a find from Kraków (ul. Zamoyskiego). In this case (an incidental grave discovery from 1886), the find was interpreted as shinbones put into an iron hoop ${ }^{25}$.

New finds were discovered in the interwar period. Worth mentioning are items from cemeteries in Barwino ${ }^{26}$,

15 Tarczyński 1899a, 2; Tarczyński 1899b, 2; Tarczyński 1900a, 20, 23; Tarczyński 1900b, 2; Rutkowski 1906a, 29, 30, Fig. 1:5; Rutkowski 1906b, 40, 42; Rutkowski 1906c, 15, Figs. 8-9; Rutkowski 1911; Krukowski 1912, 5; Lencewicz 1912, 9-10, 12.

16 Gloger 1873, 121-122; Rauhut 1971, 618, 631.

17 Amtlicher Bericht... 1897, 60; Łęga 1930, 450, 601, 613, 614.

18 Kostrzewski 1919-1920b; Rajewski 1937, 31, 43, 48, 73-74, Fig. VIII:1.

19 Kurtz 1936, 34-35, 62; Langenheim 1936, 282-285, Fig. 7:1; Wachowski 1975, 42-43, 134, 136, Fig. 31:1

20 Rajewski 1937, 33, 48, 73-74, Fig. VIII:2.

21 Wachowski 1975, 43, 87.

22 Kostrzewski 1919-1921a, 141, 143, 146, Fig. XV:6.

23 Langenheim 1936, 280; Wachowski 1975, 43, 98.

24 Langenheim 1939, 55. Until c. 1850 it was believed in Western European scholarship that hoops discovered in graves were crowns, given as grave goods to the prominent dead (Deck 1851; Cochet 1857, 282).

25 Żurowski 1923, 129.

26 Eggers 1939, 46, Fig. with no number. 
Białe Piątkowo ${ }^{27}$, Gnieszowice ${ }^{28}$, Goszyce ${ }^{29}$, Samborzec $^{30}$ and Dąbrowa Górnicza-Strzemieszyce Wielkie ${ }^{31}$.

In the next decades there were many new publications of finds from cemeteries in the territory of Poland, which gradually enlarged the source basis of the discussed category of finds. It is worth mentioning sites with more numerous burials containing buckets: Brześć Kujawski ${ }^{32}$, Cedynia, Site $2 \mathrm{a}^{33}$, Daniłowo Małe ${ }^{34}$, Dębina ${ }^{35}$, Końskie ${ }^{36}$, Lubień ${ }^{37}$, Młodzikowo $^{38}$, Płock-Podolszyce ${ }^{39}$, Psary-Lechawa ${ }^{40}$, Stary Zamek $^{41}$, Tomice ${ }^{42}$ and Żukowo ${ }^{43}$. Also individual graves containing such vessels were analysed, although buckets were not the main subject of discussion. These graves are: Czersk, Grave 60944; Ciepłe, Grave 4245; Imielno, Grave 156; Pień, Grave 1577; Radom, Grave 2948; Sandomierz, Site 45, Grave with no number ${ }^{49}$; Sowinki, Grave $70^{50}$.

In the recent years we have had an opportunity to learn about interesting assemblages of buckets discovered in cemeteries in Daniszewo ${ }^{51}$, Kałdus, Site $4^{52}$, Pień ${ }^{53}$, Ciepłe $^{54}$, Czarna Wielka ${ }^{55}$ and Bodzia ${ }^{56}$.

It must be added that in some of the mentioned works analyses were carried out on finds acquired during earlier

27 Rajewski 1937, 30, 31, 48, 49, 73-74, Figs. VIII:6-7.

28 Gardawski and Miszkiewicz 1956, 163, 169; Figs. 1, XXXVI:3.

29 Bartys 1935-1936a, 181-182.

30 Bartys 1935-1936b, 174, 173, 176.

31 Marciniak 1930-1932, 239, Fig. 3.

32 Kaszewscy 1971, 392-393, Figs. III:19, V:1, 3-4, VII:19-20, IX.

33 Porzeziński 2006, 74-75, 173-175, Figs. VI, XXI:125, XLVII:k.

34 Krasnodębski 1999, 215, 216; Koperkiewicz and Krasnodębski 2002, 247, 278-279 [Tab. 1], Fig. 5; Koperkiewicz and Krasnodębski 2006, 474, Figs. 13:c, 14.

35 Pokuta and Wojda 1979, 104, Figs. V:172, XII:1.

36 Gąssowski 1950, 136, Fig. XI:7.

37 Kurasiński and Skóra 2012a, 57-60, Figs. V:6, VII:2, X:6,

XIX:2, XXXVII:6, XLIII:6, LXVI:4.

38 Leciejewicz and Łosiński 1960, 159, Figs. 37, 46:2, 48:1-5, $61: 1-5$.

39 Kordala 1992, 34, Figs. XI:1, XII:1-2, XXV:1.

40 Trębaczkiewicz 1963, 143-144, Fig. VII:2.

41 Wachowski 1992, 22-23, 40-41, Fig. 18:b.

42 Wachowski 1973, 183, 198, Fig. 87:a.

43 Dzik 2006, 85-89, Figs. 54:1-3, 55:1-4.

44 Rauhutowa 1972.

45 Ratajczyk 2013a.

46 Pawlak et al. 2006.

47 Drozd and Janowski 2007.

48 Kurasiński and Skóra 2012b.

49 Florek 2006.

50 Krzyszowski 1997.

51 Sawicki 2008, 164, 182, Fig. 5:1.

52 Chudziak et al. 2010, 90, 93; Bojarski et al. 2010, 560, Figs. 97-98:g.

53 Drozd et al. 2009, 354-355, 359 [Tab. 1]; Janowski 2013, 398.

54 Ratajczyk 2011, 566; Ratajczyk 2013b, 335ff, Figs. 10, 12, 14, 17.

55 Bieńkowska et al. 2013, 78, 101, 103, Figs. LXXII-

LXXIII:2, CXVIII:1, CXX-CXXI:8, 16-19; Dzik 2014, 205-206.

56 Zamelska-Monczak 2015. excavations ${ }^{57}$, which sometimes means a loss of some data. This first of all concerns artefacts which are easily prone to destruction and which are not always properly handled, such as wooden stave vessels. Anyway, this bulk of complete data, both with regard to characteristics of artefacts themselves and contexts of their discoveries, offers possibilities for a more comprehensive assessment of the phenomenon of furnishing graves with stave vessels.

In some works these containers became a subject of more in-depth discussion, which goes beyond a mere descriptive presentation of the assemblage. One can point to a monograph of the cemetery in Żukowo, where the author discussed the problem of buckets' content, taking into consideration a possibility that not all artefacts deposited into graves were necessarily filled with some content. Some of them may have contained water only. The author of this monograph also proposed that the disappearance of the habit of providing the dead with buckets may have been a reflection of changes in the structure of Early Medieval tableware, where buckets were replaced with clay vessels, which were deposited into graves during a longer period ${ }^{58}$.

A separate discussion is required in the case of publications dealing with not hitherto mentioned cemeteries in Lutomiersk and Kraków-Zakrzówek. In these works, a typological classification of the discussed artefacts was proposed, but solely on the basis of finds from these two sites. In both cases construction traits were taken as criteria of division. Two types were isolated with regard to finds from Lutomiersk. The first type includes vessels with iron hoops and bails, and sometimes handles in the form of iron rings. The other type encompassed analogical items, which were additionally fitted with external bands of iron sheet. Buckets with no metal sheet cover are the most widespread form and display a considerable degree of standardisation. On the other hand, iron-fitted containers are more diversified, although the way of their manufacture is similar ${ }^{59}$. A more detailed classification was worked out for the assemblage of 7 finds from Kraków-Zakrzówek. Analogously to the Lutomiersk artefacts, two types of stave vessels were isolated. In this typology, the shape of the container was assumed to be a principal trait. Type I included one cylindrical find, provided with three hoops and with no bail. Type II encompassed "proper" buckets, in the shape of a chamfered cone. All buckets of this type were provided with bails. On the basis of the kind and number of fittings such vessels were divided into 3 variants: a - with three hoops and hasp-shaped catches, b - with four hoops and plate-shaped catches, and $\mathrm{c}-$ with a decorative fitting of staves $^{60}$.

57 Końskie - excavations in 1925; Brześć Kujawski - 19341938; Lubień - 1971-1974; Żukowice - 1955; Radom - 1966; Czarna Wielka - 1951-1978.

58 Dzik 2006, 88-89.

59 Nadolski et al. 1959, 95-99.

60 Morawski and Zaitz 1977, 138-139. 
A slightly more abundant bulk of information concerning buckets (which was a result of an enlarged source basis), with some degree of discussion on the very phenomenon of furnishing graves with artefacts of this kind, can be found in compendia on funeral rites in the entire territory of Poland ${ }^{61}$ or in larger territorial units ${ }^{62}$. Encyclopaedic entries by A. Niesiołowska-Wędzka ${ }^{63}$ and H. Steuer ${ }^{64}$, which were based on European finds (including Slavic ones), can be treated as an introduction to research on the discussed category of artefacts.

Individual finds and larger assemblages were also sporadically analysed. The first case concerns finds discovered in the cemeteries in Lubien, Grave $9\left(11^{\text {th }} \mathrm{c}\right.$.) and in Glinno, Grave $18\left(11^{\text {th }}\right.$-beginning of the $12^{\text {th }}$ c. $)$. A principal trait which distinguishes these vessels is a circumferential covering of the wooden surface with iron sheet. The first bucket was fitted with band-like stripes of metal. On the surface, between two central hoops there are small knobs forming a zigzag line. Staves were made from larch wood. This vessel is related to Scandinavian artefacts, although no direct analogies could be found. It is therefore possible that for the manufacture of this vessel North European patterns were merely used as inspiration ${ }^{65}$. The other find was made from yew wood staves, using two kinds of fittings. The part near the rim was surrounded with a band of iron sheet, and crescent-shaped appliqués forming a row arrangement were fitted below. The most numerous assemblage of finds with similar ornaments was recorded in the territory of Poland (Cedynia, Końskie, Kraków-Zakrzówek, PoznańŚródka, Sowinki). Examples from other countries include individual finds from Moravia $\left(9^{\text {th }} \mathrm{c}\right.$.) and Croatia (end of the $8^{\text {th }} \mathrm{c}$.). A modest comparative basis, which is also quite different with regard to its chronology (in the case of finds from Moravia and Croatia) offers no firm grounds to classify the find as an import, although the very idea of ornamenting vessels with the use of a crescent motif may have come from Slavic lands located to the south of the territory of Poland. It cannot be excluded that also this artefact was inspired by foreign patterns and technological solutions ${ }^{66}$.

A comprehensive assessment (with regard to construction and raw materials - yew wood) was carried out for buckets discovered in the cemetery in Poznań-Śródka (Graves 37 and 69) ${ }^{67}$. On the basis of it guidelines were pro-

61 Miśkiewicz 1969, passim.

62 Rajewski 1937, 73-74; Zoll-Adamikowa 1971, 115; Wachowski 1975, 42-44; Kufel-Dzierzgowska 1975, 379; Kordala 2006, 192-194; Pollex 2010, 175.

63 Niesiołowska-Wędzka 1980.

64 Steuer 1986.

65 Kurasiński 2012.

66 Kurasiński 2015 a.

67 Other buckers were also found at this site; regrettably, they are known from short mentions only (Pawlak 2005, 64, Figs. 7:2, 4; Pawlak and Pawlak 2007, 76, Figs. 4, 7, 11; Pawlak and Pawlak 2015, 64, Fig. 64). posed which enabled the researcher to estimate the capacity of containers of this kind. Acquired results were compared with finds from other selected necropoles in the territory of Poland $^{68}$. This work also discussed the issue of funeral significance of stave vessels. It was proposed that such vessels were manufactured with an intention to deposit them into graves, and therefore they had no use in daily household activities $^{69}$.

From a cognitive point of view, of great importance is a recently published assemblage of buckets (11 items which were certainly identified) from the cemetery in Sowinki ${ }^{70}$. Apart from a very detailed characteristics of sources and a catalogue of graves with stave vessels (as well as with clay vessels), which is also provided with complete anthropological and archaeological data, the paper discusses results of palaeobotanic and chemical analyses. It turned out that buckets were made from wood of coniferous trees (remains of pine wood and yew wood where found where it was possible). Furthermore, the analysis of microremains taken from vessels discovered in Graves 148 and 151 demonstrates that these vessels contained meat dishes (without bones). It is possible that grains of cereals or seeds of oleaginous plants with an addition of wine or beer dissolved in water were put into the container from Grave 70. Diluted alcohol may have also been present in other containers (Graves 157, 176, and 182). Food of unspecified kind was also placed in the vessel from Grave $176^{71}$. A. Krzyszowski also expressed his opinion on the function of buckets deposited into the graves, saying that the presence of these vessels not only speaks of funeral rites of those days, which were still rooted in the pagan world, but also of the social position of the buried person $^{72}$.

Other findings which are worth mentioning can also be found in studies concerning broader issues related to funeral rites. The question of topographical distribution of grave goods, including buckets, in graves in so-called stone casings in Masovia was analysed by P. Kościelecki ${ }^{73}$. His studies suggest that these vessels were most often found in male burials and were part of military equipment. They were almost always placed near the feet of the deceased person and were a testimony of continuation of earthly life in the other world ${ }^{74}$.

It is also necessary to mention the work of W. Rohrer, devoted to ethnic interpretation of Early Piast burials ${ }^{75}$. In a separate chapter W. Rohrer critically assesses opinions suggesting a North European (mainly Scandinavian) provenance

68 Pawlak 1999, 115-121, Fig. 2.

69 Pawlak 1999, 120.

70 Krzyszowski 2014.

71 Krzyszowski 2014, 140-146, 149; cf. also Krzyszowski 1995,61 .

72 Krzyszowski 2014, 152.

73 Kościelecki 2000, 69-70 and passim.

74 Kościelecki 2000, 69, 74-76.

75 Rohrer 2012. 
of some buckets from the territory of Poland, with special reference to finds fitted with metal sheets ${ }^{76}$. This researcher questioned the interpretation of such containers as ethnic determinants of social pertinence ${ }^{77}$.

Problem-oriented broader works are relatively rare. One of these is a work discussing vessels found in graves which contained weaponry ${ }^{78}$. In the section discussing buckets several conclusions were drawn, which put in question hitherto expressed opinions as not supported with available source data. First of all, an assumption was questioned that vessels placed in graves were made only for this purpose. It can be supposed that most of such vessels were used in daily life and they were personal property (and a status symbol) of the buried person. Therefore, a new (ritual and sepulchral) function of the discussed vessels, which was related to a broadly understood cult of the dead, retained its hitherto utilitarian nature - for drawing, spilling, storing and consuming of mostly liquid substances ${ }^{79}$. Furthermore, a well-established theory on buckets as part of military equipment of horsemen and thus as typically male attributes could not be confirmed. Such containers found their way not only to graves of retinue warriors or other representatives of social elites, but also to graves of lower rank combatants, buried without spurs or swords, which are believed to have been military determinants of prestige. Moreover, buckets were placed in graves of women and children, as well as of men interred with no weaponry at all ${ }^{80}$. Doubts were also provoked by the interpretation of "grave" buckets as drinking-troughs for horses, chiefly due to their usually small capacity ${ }^{81}$. The afore-mentioned assumption of M. Dzik concerning the disappearance of buckets in cemeteries as a reflection of tendency to replace wooden containers with ceramic ones in tableware was also considered as doubtful. However, a need for further comprehensive studies on this issue was stressed ${ }^{82}$.

Some of the afore-mentioned issues appeared in more recent works. An inconvenience of interpretation of buckets in graves as artefacts whose manufacture was solely dictated by needs of funeral rites commences to be seen. This has recently been expressed in a work discussing finds from the cemetery in Bodzia ${ }^{83}$.

Problems of the presence of buckets in children's burials have also been dealt with. It was proposed that burying

76 Cf. e.g. Jankuhn 1934, 314; Langenheim 1936, 279, 285; Jażdżewski 1949, 150-151; Jażdżewski 1950, 258; Skalski 1995, 91. Vessels covered with metal sheets which are found in Early Medieval cemeteries in Poland are usually believed to be Swedish or Danish imports. Such a direction was suggested in the case of buckets discovered in chamber graves at Kałdus (Chudziak 2002, 439; Chudziak 2003a, 150; Chudziak 2003b, 120).

77 Rohrer 2012, 106-108.

78 Janowski and Kurasiński 2008.

79 Janowski and Kurasiński 2008, 70-72.

80 Janowski and Kurasiński 2008, 66-72.

81 Janowski and Kurasiński 2008, 68-69.

82 Janowski and Kurasiński 2008, 69.

83 Zamelska-Monczak 2015, 301. children with such containers was a significant element of creation and communication of the social position of the dead. This, however, does not exclude other possibilities of interpretation, especially those related to the cult of the $\operatorname{dead}^{84}$.

Yet another paper attempted at assessing the phenomenon of burying the dead with buckets in a perspective of ideological and religious changes which took place in the territory of Poland in the Early Middle Ages. In the present state of research this phenomenon seems to be quite ambivalent, which results from complex (and changing) relations between the old system of beliefs and the Christian faith. It seems that buckets in graves were related to the cult of the dead, which was manifested in common feasting of the living with the dead. Buckets were filled with drinks and food, which were meant to facilitate the dead person's travel to the other world and to protect against their unwanted return. Therefore, burying the dead with buckets gave reasons for anxiety in ecclesiastical spheres, as this rite was too strongly at odds with Christian recommendations for funeral rites and was too strongly associated with pagan traditionalism ${ }^{85}$.

Eventually, it is possible to state the most ardent research needs related to the issue mentioned in the title of this paper. First of all, it is necessary to carry out a macroscopic assessment of all surviving remains of buckets. A detailed examination will make possible not only to more or less comprehensively reconstruct metrical data of a given vessel (hoops' diameters) and applied technological solutions, but it will also allow for making numerous other observation. For instance, a careful inspection of strongly destroyed metal elements of the afore-mentioned container from Glinno enabled the researchers to isolate fragments of sheet band from its covering and crescent-shaped appliqués which decorated its surface. It is also worth noting that there is a small number of vessels whose catches differ with regard to their shapes (a repairing procedure). This can suggest that these finds had been in use before they became part of post mortem furnishings.

Furthermore, specialist analyses should also be intensified, as there is a strong deficiency of such examinations. Obviously, a possibility to carry out such analyses is limited with availability of well-preserved finds. It is known that stave vessels are especially prone to decomposition processes, both in the soil and later on, when they are kept in storeroom conditions. Such vessels are usually not secured properly and they do not undergo necessary conservation treatment. It seems, however, that a careful selection could yield a statistically significant series of samples which could be classified with regard to their taxonomy, or could at least enlarge the number of available samples. So far, it has

\footnotetext{
84 Kurasiński, in press.

85 Kurasiński 2015 b.
} 
been possible to identify species of wood only in 17 cases of vessels known from graves. In all cases the presence of tissues of coniferous trees was identified, with a notable preponderance of yew wood ${ }^{86}$. An acquisition of a possibly broad scope of results would be of strong significance for an assessment of sepulchral function of buckets. A confirmation of dominance of yew wood would offer an interesting field of debate on symbolism of discusses vessels, taking into consideration biological properties of yew ${ }^{87}$ and welldeveloped beliefs related to this tree ${ }^{88}$. This also concerns finds made from staves and bottoms of this wood which are known from non-cemetery sites ${ }^{89}$.

Furthermore, metallographic examinations and X-ray photos also provide numerous valuable pieces of information concerning technical and technological aspects of manufacture of these containers and their possible ornaments. There may have been practical reasons behind the selection of a given material. Phosphorus influences iron's fragility, especially in low temperatures. Therefore, the selection of low-phosphorus iron was perhaps to protect against damages to which construction details of buckets were exposed ${ }^{90}$. The surface of hoops of one vessel from the cemetery in Lubien was tinned. This could be explained with an intention to ornament the bucket or to protect it against too quick wear ${ }^{91}$. Differences in percentage share of elemental composition in individual construction parts, which testify to heterogeneity of raw materials, may suggest that these parts got worn out and therefore they needed replacement. This sheds a different light on the issue of strictly funeral destination of buckets deposited into graves. The replacement of worn out details implies that these buckets functioned in daily life. On the other hand, one must also be aware that different chemical compositions of metal parts were also influenced by other factors (e.g., different provenance of raw materials). Regrettably, analyses of this kind are also carried out sporadically, mainly due to a poor state of preservation of discussed vessels. This is also caused by a false assumption that this group of finds is of minor cognitive value.

86 Cf. Kurasiński 2015a, 196-197; with relevant scholarship.

${ }^{87}$ Yew wood is remarkable for its very favourable technological and utilitarian properties, such as durability and resistance in changing humidity conditions. Therefore, this raw material was perfectly suitable for vessels designed to store liquids (Molski 1968, 494; Szydłowski 1984, 52). Of significance was also its reddark brown hue, which improved visual values of the container (Kaźmierczyk 1965, 473). On the other hand, yew belongs to very toxic plants, both for humans and animals, especially horses (Seneta and Dolatowski 2000, 28).

88 Cf. Agapkina 2012; Kurasiński 2015b, 156-157, 190.

89 E.g. Stępnik 1996, 272, Tab. 4; Stępnik 2014, 175-176, Tab. 48; Myśkow and Rakoczy 2015, 364 [Tabl. 1], 368.

90 Piaskowski 1959, 126.

91 Kurasiński and Skóra 2012a, 58. Tin cover was found on four hoops and two bows of buckets discovered at the stronghold in Opole-Ostrówek. It was believed that this cover was to stress both aesthetic values of vessels as well as their special use.
Moreover, analyses allowing for identification of original contents of buckets become indispensable. The importance of this kind of information is fully demonstrated by results of chemical analyses of the buckets from Sowinki, which enable the researcher to draw conclusions with regard to the role of these vessels in Early Medieval funeral rites. Of significance are also detailed examinations of the space within hoops and - in case organic remains are present - identification of these remains. Animal bones are sometimes found in buckets. For instance, a fragment of a pig jaw was found at Poznań-Śródka ${ }^{92}$. Although buckets are not mass finds in graves, research projects on cemeteries should possibly consider taking of relevant samples and later examinations of their nature.

Furthermore, it is worth taking measurements of remains of vessels already at the stage of in situ examinations. This may facilitate reconstructions of their shapes and sizes. Of significance are also observations on the context of discoveries, concerning the place of the container in relation to human remains and grave structures (if such structures are identifiable). ${ }^{93}$

Cognitively valuable observations can also be expected from comparisons between vessels from cemeteries and from other types of sites. Did they actually differ, as some researchers maintained? Qualitative and quantitative comparisons of stave vessels and clay (and other) vessels which were given to the dead as grave goods can be of equal cognitive value.

Finally, we would like to hope that the gap in research on stave vessels from funeral contexts will be filled by a monograph on this issue, which is being prepared by the author of this paper. It will be based on an assemblage of about 350 buckets (or, strictly speaking, remains of such vessels) from the territory of present-day Poland, known from more than 100 necropoles or isolated burials. So-called stray finds will be excluded from examinations, although it is very probable that they were originally part of contents of destroyed graves.

92 Pawlak and Pawlak 2007, 76, 84.

93 A careful examination of the complex case of Grave 24 from Ostrowite allowed to state that each person who was subsequently buried in the grave was provided with the mentioned vessel (for a detailed description cf. Drozd-Lipińska et al. 2013, 228). 


\section{Bibliography}

Agapkina T. A. 2012. Simvolika derev'ev v tradicionnoj kul'ture slavân: tis (Taxus baccata). „Slavânskij almanah” 2012, 365-375.

Amtlicher Bericht... 1897. Amtlicher Bericht über die Verwaltung der naturhistorischen, archäologischen und ethnologischen Sammlungen des Westpreussischen Provinzial-Museums für das Jahr 1896 17. Danzig, 47.

Barnycz-Gupieniec R. 1959. Naczynia drewniane z Gdańska w X-XIII wieku. Acta Archaeologica Universitatis Lodziensis 8. Gdańsk.

Bartys J. 1935-1936a. Materjały prehistoryczne z Goszyc, pow. miechowski. „Przegląd Archeologiczny” 5 (2-3), 181-185.

Bartys J. 1935-1936b. Wczesnośredniowieczne cmentarzysko szkieletowe we wsi Samborzec, pow. Sandomierz. „Przegląd Archeologiczny" 5 (2-3), 171-180.

Bieńkowska A., Dzik M., Piasecka K. 2013. Średniowieczne cmentarzysko w Czarnej Wielkiej, stan. 1, woj. podlaskie (badania 1951-1978) 1. Białystok.

Bojarski J., Chudziak W., Drozd A., Koperkiewicz A., Kozłowski T., Stawska V. 2010. Katalog źródet. In: W. Chudziak (ed.), Wczesnośredniowieczne cmentarzysko szkieletowe w Kałdusie (stanowisko 4). Mons Sancti Laurentii 5. Toruń, 189-603.

Bronicka-Rauhut J. 1998. Cmentarzysko wczesnośredniowieczne w Czersku. Warszawa.

Chudziak W. 2002. Ślady skandynawskiej obrzędowości w Kałdusie na Pomorzu Wschodnim. In: J. Wrzesiński (ed.), Popiót $i$ kość. Funeralia Lednickie 4. Sobótka, Wrocław, 433-447.

Chudziak W. 2003a. Wikingerzeitliche Spuren des skandinavischen Brauchtums in Kałdus (Ostpommern). „Archäologisches Korrespondenzblatt” 33 (1), 143-156.

Chudziak W. 2003b Wczesnośredniowieczne „importy” skandynawskie z Katdusa pod Chetmnem na Pomorzu Wschodnim. In: M. Dulinicz (ed.), Słowianie i ich sasiedzi we wczesnym średniowieczu. Lublin, Warszawa, 117-126.

Chudziak W., Bojarski J., Stawska V. 2010. Wyposażenie pochówków. In: W. Chudziak (ed.), Wczesnośredniowieczne cmentarzysko szkieletowe w Kałdusie (stanowisko 4). Mons Sancti Laurentii 5. Toruń, 79-126.

Cochet J. B. D. 1857. Sépultures gauloises, romaines, franques et normandes, faisant suite à „La Normandie Souterraine”. Paris.

Deck I. 1851. Notice of Remains of the Anglo-Saxon Period, discovered at Little Wilbraham, Cambridgeshire. „Archaeological Journal" 8, 172-175.

Dołżycka B. 1996. Naczynia klepkowe do czerpania i noszenia wody. In: J. Bohdanowicz (ed.), Komentarze do Polskiego Atlasu Etnograficznego 3. Wrocław, 180-194.

Drozd A., Janowski A. 2007. Wczesnośredniowieczny grób komorowy z Pnia. In: W. Dzieduszycki, J. Wrzesiński (eds.), Środowisko pośmiertne człowieka. Funeralia Lednickie 9. Poznań, 163-168.

Drozd A., Janowski A., Poliński D. 2009. Wczesnośredniowieczne groby komorowe na cmentarzysku w Pniu koło Bydgoszczy (badania 2005-2007). In: A. Janowski, K. Kowalski, S. Słowiński (eds.), XVI Sesja Pomorzoznawcza, Szczecin 22-24 listopada 2007 r. 1. Acta Archaeologica Pomoranica 3. Szczecin, 351-366.

Drozd-Lipińska A., Pudło P., Sikora J., Trzciński Ł., Wroniecki P. 2013. Wczesnośredniowieczny zespół osadniczy w Ostrowitem, gm. Chojnice, w świetle badań z lat 2010-2011. In: E. Fudzińska (ed.), XVIII Sesja Pomorzoznawcza 1: od epoki kamienia do wczesnego średniowiecza. Materiały z konferencji 16-18 listopada. Malbork, 217-240.

Dzik M. 2006. Wczesnośredniowieczne cmentarzysko szkieletowe w Żukowie, pow. Płońsk. Światowit Supplements Series P: Prehistory and Middle Ages 13. Warszawa.

Dzik M. 2014. Pozostałe zabytki ruchome. In: H. Karwowska (ed.), Średniowieczne cmentarzysko w Czarnej Wielkiej, stan. 1, woj. podlaskie (badania 1951-1978) 2. Białystok, 205-213.

Eggers H. J. 1939. Ein Gräberfeld der wendisch-wikingischen Zeit bei Barvin, Kr. Rummelsburg. „Monatsblätter der Gesellschaft für Pommersche Geschichte und Altertumskunde" 53 (2), 45-47.

Florek M. 2006. Wczesnośredniowieczny pochówek szkieletowy z Sandomierza. „Wiadomości Archeologiczne” 58, $410-412$.

Gardawski A., Miszkiewicz B. 1956. Cmentarzysko wczesnośredniowieczne w Gnieszowicach pow. Sandomierz. „Materiały Wczesnośredniowieczne" 4, 163-170.

Gąssowski J. 1950. Cmentarzysko w Końskich na tle zagadnienia południowej granicy Mazowsza we wczesnym średniowieczu. „Materiały Wczesnośredniowieczne” 2, 71-175.

Gloger Z. 1873. Osady nad Niemnem i na Podlasiu z czasów użytku krzemienia. „Wiadomości Archeologiczne” 1, 97-124.

Itman L. 1955. Przyczynek do znajomości rzemiosła bednarskiego w Polsce. Archiwum Etnograficzne 8. Wrocław.

Jankuhn H. 1934. Der Wikingerfund aus Libau in der Provinz Posen. „Altschlesien” 5, 309-317.

Janowski A. 2013. Are the chamber graves from Pień really Scandinavian? In: S. Moździoch, B. Stanisławski, P. Wiszewski (eds.), Scandinavian Culture in Medieval Poland. Interdisciplinary Medieval Studies 2. Wrocław, 395-409. 
Janowski A., Kurasiński T. 2008. (Nie)militarne naczynia. Fakty i mity. In: W. Świętosławski (ed.), Nie tylko broń. Niemilitarne wyposażenie wojowników w starożytności i średniowieczu. Acta Archaeologica Lodziensia 54. Łódź, 61-88.

Jażdżewski K. 1949. Cmentarzysko wczesnośredniowieczne w Lutomiersku pod Łodzia w świetle badań z r. 1949. „Materiały Wczesnośredniowieczne" 1, 91-191.

Jażdżewski K. 1950. Sprawozdanie z badań archeologicznych na cmentarzysku wczesnośredniowiecznym w Lutomiersku w pow. łaskim (woj. łódzkie) wr. 1950. „Materiały Wczesnośredniowieczne” 2, 257-264.

Kaszewscy E. i Z. 1971. Wczesnośredniowieczne cmentarzysko w Brześciu Kujawskim, pow. Włocławek. „Materiały Starożytne i Wczesnośredniowieczne" 1, 365-434.

Kaźmierczyk J. 1965. Wczesnośredniowieczne wyroby bednarskie z Ostrówka w Opolu. „Kwartalnik Historii Kultury Materialnej" 13 (3), 469-498.

Koperkiewicz A., Krasnodębski D. 2002. Cmentarzysko z okresu wczesnego średniowiecza w Daniłowie Małym, gm. Łapy, woj. podlaskie. Sprawozdanie z prac przeprowadzonych z roku 2001 oraz wstęne podsumowanie wyników badań. In: M. Karczewska, M. Karczewski (eds.), Badania archeologiczne w Polsce pótnocno-wschodniej i na zachodniej Białorusi w latach 2000-2001. Materiały z konferencji, Białystok 6-7 grudnia 2001 roku. Białystok, 271-282.

Koperkiewicz A., Krasnodębski D. 2006. Wczesnośredniowieczne cmentarzysko w Daniłowie Małym, gm. Łapy. In: W. Chudziak, S. Moździoch (eds.), Stan i potrzeby badań nad wczesnym średniowieczem w Polsce - 15 lat później. Toruń, Wrocław, Warszawa, 465-485.

Kordala T. 1992. Cmentarzysko z XI-XII wieku w Płocku-Podolszycach. „Rocznik Muzeum Mazowieckiego w Płocku” 15, 3-96.

Kordala T. 2006. Wczesnośredniowieczne cmentarzyska szkieletowe na pólnocnym Mazowszu. Łódź.

Kostrzewski J. 1919-1920a. Cmentarzysko z śladami kultury wikingów w Łubówku, w pow. gnieźnieńskim. „Przegląd Archeologiczny" 1 (3-4), 140-147.

Kostrzewski J. 1919-1920b. Badania archeologiczne w Wierzenicy w powiecie poznańskim wschodnim. „Zapiski Muzealne” 4-5, 30-40.

Kościelecki P. 2000. Topografia wyposażenia grobów męskich na staromazowieckich cmentarzyskach z grobami w obudowach kamiennych z XI-XIII wieku. „Studia i Materiały Archeologiczne” 10, 55-88.

Krasnodębski D. 1999. Ratownictwo archeologiczne na trasie budowy gazociagu jamalskiego we wschodniej części województwa podlaskiego. „Biuletyn Konserwatorski Województwa Podlaskiego” 5, 211-220.

Krukowski S. 1912. Cmentarz grzebalny w Koziminach (powiat Płoński). „Światowit” 10, 1-7.

Krzyszowski A. 1995. Ein reiches Gräberfeld aus dem 10./11. Jh. in Sowinki bei Poznań. „Slavia Antiqua” 36, 49-71.

Krzyszowski A. 1997. Frühmittelalterliches Grab eines Kaufmannes aus Sowinki bei Poznań in Großpolen. „Germania” 75 (2), 639-667.

Krzyszowski A. 2014. Naczynia ceramiczne i wiaderka klepkowe z wczesnopiastowskiego cmentarzyska w Sowinkach k. Poznania. In: T. Kurasiński, K. Skóra (eds.), Grób w przestrzeni, przestrzeń w grobie. Przestrzenne uwarunkowania w dawnej obrzędowości pogrzebowej. Acta Archaeologa Lodziensia 60. Łódź, 137-158.

Kufel-Dzierzgowska A. 1975. Wczesnośredniowieczne cmentarzyska szkieletowe w Polsce środkowej. „Prace i Materiały Muzeum Archeologicznego i Etnograficznego w Łodzi. Seria Archeologiczna” 22, 374-390.

Kurasiński T. 2012. Wiadro obite blacha z wczesnośredniowiecznego cmentarzyska w Lubieniu, pow. piotrkowski. In: A. Jaszewska (ed.), Z najdawniejszych dziejów. Grzegorzowi Domańskiemu na pięćdziesięciolecie pracy naukowej. Zielona Góra, 291-303.

Kurasiński T. 2015a. Wiadro obite blaszanymi okuciami z wczesnośredniowiecznego cmentarzyska w Glinnie w świetle dotychczasowych znalezisk europejskich. „Slavia Antiqua” 56, 191-208.

Kurasiński T. 2015b. Burials with Buckets in Early Medieval Poland: A Pagan or Christian Custom? In: L. Gardeła, A. Půlpánová-Reszczyńska (eds..), Rituals in the Past. Analecta Archaeologica Ressoviensia 10. Rzeszów, $137-198$.

Kurasiński T. in press a. A Child with a Bucket. A Study of Grave Goods in Children's Graves in the Polish lands in the Early Middle Ages. „Archaeologia Polona”.

Kurasiński T., Skóra K. 2012a. Wczesnośredniowieczne cmentarzysko szkieletowe w Lubieniu, pow. piotrkowski. Łódź.

Kurasiński T., Skóra K. 2012b. Militaria z wczesnośredniowiecznego cmentarzyska szkieletowego w Radomiu, stan. 4. „Acta Militaria Mediaevalia" 8, 69-89.

Kurtz H. 1936. Slawische Bodenfunde in Schlesien. Breslau.

Langenheim K. 1936. Die Bedeutung der Wikinger für Schlesiens Frühgeschichte. „Altschlesien” 6 (2), 273-316.

Langenheim K. 1939. Nochmals „,Spuren der Wikinger um Truso”. „Gothiskandza” 1, 52-62.

Leciejewicz L., Łosiński W. 1960. Wczesnośredniowieczne cmentarzysko w Młodzikowie w pow. średzkim. „Fontes Archaeologici Posnanienses" 11, 104-165.

Lencewicz S. 1912. Cmentarzyska grzebalne w pow. Płońskim. „Światowit” 10, 9-13. 
Łęga W. 1930. Kultura Pomorza we wczesnem średniowieczu na podstawie wykopalisk. Toruń.

Marciniak J. 1930-1932. Tymczasowe wyniki badań przeprowadzonych na cmentarzysku wczesnohistorycznem w Strzemieszycach Wielkich, w powiecie będzińskim. „Przegląd Archeologiczny” 4 (3), 238-241.

Miśkiewicz M. 1969. Wczesnośredniowieczny obrzadek pogrzebowy na płaskich cmentarzyskach szkieletowych w Polsce. „Materiały Wczesnośredniowieczne” 6, 241-301.

Mały słownik... 1990. Mały słownik języka polskiego, S. Skorupka, H. Auderska, Z. Łempicka (eds.). Warszawa.

Molski B. 1968. Gatunki drewna używane w'średniowiecznym Szczecinie do wyrobu przedmiotów codziennego użytku. „Archeologia Polski” 13 (2), 491-502.

Morawski W., Zaitz E. 1977. Wczesnośredniowieczne cmentarzysko szkieletowe w Krakowie na Zakrzówku. „Materiały Archeologiczne" 17, 53-169.

Moszyński K. 1967. Kultura ludowa Stowian 1: Kultura materialna. Warszawa.

Myśkow E., Rakoczy M. 2015. Identyfikacja rodzaju drewna wykorzystanego do wyrobu zabytków drewnianych z badań archeologicznych przy ulicy św. Idziego. In: A. Limisiewicz, A. Pankiewicz (eds.), Kształtowanie się grodu na wrocławskim Ostrowie Tumskim. Badania przy ul.św. Idziego/The Development of the Stronghold on Ostrów Tumski in Wrocław. Research at św. Idziego Street. Wrocław, 363-372.

Nadolski A., Abramowicz A., Poklewski T. 1959. Cmentarzysko z XI wieku w Lutomiersku pod Łodzią. Acta Archaeologica Universitatis Lodziensis 7. Łódź.

Niesiołowska-Wędzka A. 1980. Wiadra. In: G. Labuda, Z. Stieber (eds.), Słownik starożytności słowiańskich 6 (2). Wrocław, Warszawa, Kraków, Gdańsk, 407-410.

Pawlak P. 1999. Formy wykorzystania surowca drzewnego w obrzadku pogrzebowym na wczesnośredniowiecznym cmentarzysku ,szkieletowym” w Poznaniu-Śródce - przykłady i próby interpretacji. „Przegląd Archeologiczny” 47, 115-139.

Pawlak P. 2005. Cmentarzyska przedlokacyjnego Poznania. In: Z. Kurnatowska, T. Jurek (eds.), Civitas Posnaniensis. Studia z dziejów średniowiecznego Poznania. Poznań, 59-109.

Pawlak E., Pawlak P. 2007. Badania archeologiczne na wczesnośredniowiecznym cmentarzysku „szkieletowym” z PoznaniaŚródki (Rynek Śródecki 4) w 2001 roku. „Wielkopolskie Sprawozdania Archeologiczne” 8, 63-93.

Pawlak E., Pawlak P. 2015. Serce miasta jest po prawej stronie. Archeologia o przeszłości poznańskiej Śródki i Ostrówka. Poznań.

Pawlak P., Skorupka T., Strzyżewski Cz. 2006. Cmentarzysko wczesnośredniowieczne w Imielnie, stan. 33, woj. wielkopolskie. „Fontes Archaeologici Posnanienses” 42, 157-173.

Piaskowski J. 1959. Metaloznawcze badania wyrobów żelaznych. In: A. Nadolski, A. Abramowicz, T. Poklewski, Cmentarzysko z XI wieku w Lutomiersku pod Łodzią. Acta Archaeologica Universitatis Lodziensis 7. Łódź, 110-139.

Pokuta Z., Wojda L. 1979. Wczesnośredniowieczne cmentarzysko we wsi Dębina, woj. sieradzkie. „Prace i Materiały Muzeum Archeologicznego i Etnograficznego w Łodzi. Seria Archeologiczna” 26, 89-142.

Pollex A. 2010. Glaubensvorstellungen im Wandel. Eine archäologische Analyse der Körpergräber des 10. bis 13. Jahrhunderts im nordwestslawischen Raum. Rahden/Westf.

Porzeziński A. 2006. Wczesnośredniowieczne cmentarzysko szkieletowe na stanowisku $2 a$ w Cedyni, województwo zachodniopomorskie. Szczecin.

Rajewski Z. A. 1937. Wielkopolskie cmentarzyska rzędowe okresu wczesnodziejowego. „Przegląd Archeologiczny” 6 (1), 28-85.

Ratajczyk Z. 2011. Nowe odkrycia na cmentarzysku z okresu wczesnego średniowiecza w Cieptem, gm. Gniew, stanowisko 6. In: M. Fudziński, H. Paner (eds.), XVII Sesja Pomorzoznawcza 1: Od epoki kamienia do wczesnego średniowiecza. Gdańsk, 553-570.

Ratajczyk Z. 2013a. Jednak ostrogi-brazowe okucie typu lutomierskiego w świetle najnowszych badań na cmentarzysku w Ciepłem, gm. Gniew. „Slavia Antiqua” 54, 287-305.

Ratajczyk Z. 2013b. The cemetery in Ciepłe - current research results. In: S. Moździoch, B. Stanisławski, P. Wiszewski (eds.), Scandinavian Culture in Medieval Poland. Interdisciplinary Medieval Studies 2. Wrocław, 323-351.

Rauhut L. 1971. Wczesnośredniowieczne cmentarzyska w obudowie kamiennej na Mazowszu i Podlasiu. „Materiały Starożytne i Wczesnośredniowieczne" 1, 435-656.

Rauhutowa J. 1972. Wczesnośredniowieczny grobowiec z XII w. z Czerska pod Warszawa. „Archeologia Polski” 17 (1), 143-160.

Rohrer W. 2012. Wikinger oder Slawen? Die ethnische Interpretation frühpiastischer Bestattungen mit Waffenbeigabe in der deutschen und polnischen Archäologie. Marburg.

Rutkowski L. 1906a. Cmentarzysko rzędowe w Korzybiu. „Światowit” 7, 22-31. 
Rutkowski L. 1906b. Cmentarzyska rzędowe w Rostkowie, Strzeszewie, Wierzbicy, Żachowie, Blichowie i Rogowie badane przez ś. p. Franciszka Tarczyńskiego. „Światowit” 7, 39-43.

Rutkowski L. 1906c. Cmentarzyska z grobami rzędowemi w Krasinie, Romatowie i Koziminach w pow. Sierpeckim i Płońskim, gub. Płockiej. „Światowit” 7, 3-15.

Rutkowski L. 1911. Cmentarzysko rzędowe w Święcicach (pow. Płocki). „Światowit” 9, 102-104.

Sawicki T. 2008. Wczesnośredniowieczne cmentarzysko szkieletowe w Daniszewie pod Kołem, woj. wielkopolskie. „Slavia Antiqua" 49, 149-209.

Seneta W., Dolatowski J. 2000. Dendrologia. Warszawa, ed. 3.

Skalski K. 1995. Problem wykorzystania źródeł archeologicznych do badań nad składem drużyny pierwszych Piastów. „Kwartalnik Historyczny” 102 (2), 85-96.

Stownik języka polskiego... 1997. Stownik języka polskiego, W. Doroszewski (ed.). Warszawa.

Steuer H. 1986. Eimer (archäologisches). In: H. Beck et al. (eds.), Reallexikon der Germanischen Altertumskunde 6. Berlin, New York, 584-601.

Stępnik T. 1996. Średniowieczne wyroby drewniane z Ostrowa Lednickiego-analiza surowcowa. „Studia Lednickie” 4, 261-296.

Stępnik T. 2014. Wczesnośredniowieczne zabytki drewniane z Wolina w świetle analizy surowcowej. In: B. Stanisławski, W. Filipowiak (eds.), Wolin wczesnośredniowieczny 2. Warszawa, 171-194.

Szydłowski J. 1984. Naczynia drewniane w późnej starożytności na ziemiach polskich. Katowice.

Świderski J. 1966. Produkcja wyrobów bednarskich. Warszawa, ed. 2.

Tarczyński F. 1899a. Notatki do mapy archeologicznej gub. Płockiej. „Echa Płockie i Łomżyńskie” 2 (19), 1-2.

Tarczyński F. 1899b. Notatki do mapy archeologicznej gub. Płockiej. „Echa Płockie i Łomżyńskie” 2 (24), 2.

Tarczyński F. 1900a. Groby rzędowe kamienne w pow. Płockim. „Światowit” 2, 19-27.

Tarczyński F. 1900b. Notatki do mapy archeologicznej gub. Płockiej. „Echa Płockie i Łomżyńskie” 3 (65), 1-2.

Trębaczkiewicz T. 1963. Cmentarzysko wczesnośredniowieczne we wsi Psary, pow. Piotrków Trybunalski. „Prace i Materiały Muzeum Archeologicznego i Etnograficznego w Łodzi. Seria Archeologiczna" 9, 131-166.

Wachowski K. 1973. Wczesnośredniowieczne cmentarzysko szkieletowe. In: J. Romanow, K. Wachowski, B. Miszkiewicz, Tomice pow. Dzierżoniów. Wielokulturowe stanowisko archeologiczne. Wrocław, Warszawa, Kraków, Gdańsk, $173-210$.

Wachowski K. 1975. Cmentarzyska doby wczesnopiastowskiej na Śląsku. Wrocław, Warszawa, Kraków, Gdańsk.

Wachowski K. 1992. Wczesnośredniowieczne cmentarzysko szkieletowe. In: K. Wachowski, G. Domański, Wczesnopolskie cmentarzysko w Starym Zamku. Wrocław, 7-99.

Woźnicka Z. 1961. Wyroby bednarskie i tokarskie średniowiecznego Międzyrzecza. Poznań.

Zamelska-Monczak K. 2015. Ceramic and Wooden Containers. In: A. Buko (ed.), Bodzia. A Late Viking-Age Elite Cemetery in Central Poland. Leiden, Boston, 288-303.

Zoll-Adamikowa H. 1971. Wczesnośredniowieczne cmentarzyska szkieletowe Małopolski 2: Analiza. Wrocław, Warszawa, Kraków, Gdańsk.

Żurowski J. 1923. Kraków i jego okolice w czasach przedhistorycznych. „Ziemia” 8, 123-130.

\section{Streszczenie}

\section{Naczynia klepkowe jako element wyposażenia pośmiertnego we wczesnośredniowiecznej Polsce - zarys problematyki i perspektywy badawcze}

W polskim piśmiennictwie brakuje systematycznej, zakrojonej na szeroką skalę analizy formalno-typologicznej i chronologicznej naczyń klepkowych, stanowiących element wyposażenia grobowego na wczesnośredniowiecznych cmentarzyskach z terenu dzisiejszej Polski, jak również ich funkcji sepulkralnej. Wiedza na ten temat nadal pozostaje nieusystematyzowana i rozproszona w monograficznych opracowaniach poszczególnych stanowisk, w szerszych kompendiach dotyczących obrzędowości pogrzebowej oraz w ujęciach o charakterze przyczynkarskim. Wskazane jest zatem dokonanie wstępnego przeglądu badań nad tą kategorią zabytków z uwzględnieniem potrzeb w powyższym zakresie. W artykule autor omawia kwestie terminologiczne, aktualny stan rozpoznania problematyki oraz najważniejsze postulaty badawcze związane z zagadnieniem obecności naczyń klepkowych na cmentarzyskach i interpretacją zwyczaju zaopatrywania w nie zmarłych. 